\title{
Asset Mapping as a Base for Traditional Islamic Boarding School (Pesantren) Sheep Farming Development in Ngawonggo Village, Malang Regency, Indonesia
}

\author{
Siti Azizah \\ Socio-economics Department, Faculty of Animal Science, University of Brawijaya \\ siti.azizah@ub.ac.id \\ Umi Wisapti Ningsih \\ Socio-economics Department, Faculty of Animal Science, University of Brawijaya \\ uningsih56@ub.ac.id \\ Irfan H. Djunaidi \\ Animal Nutrition Department, Faculty of Animal Science, University of Brawijaya \\ irjuna@ub.ac.id

\begin{abstract}
The research aim was to identify the assets of Ngawonngo Village, Malang Regency to support the establishment of Traditional Islamic Boarding School Sheep Farming. The study was conducted in Ngawonggo Village, Tajinan District, Malang Regency. The methods used in the research was qualitative research with descriptive data analysis. The results of the study There are six (physical, natural resources, human resources, financial, technology, and social capital) of Ngawonggo Village, Tajinan District, Malang Regency. Lack of physical, technological, and financial assets has a positive side where people will have a stronger motivation to improve their wellbeing. The potential of natural assets, human resources, and social capital can solve community problems and improve other assets that are not yet optimal. The sheep breeding business initiated by the pesantren as an influential institution is a strategic plan to develop the Tajinan Village as a center for sheep farming.
\end{abstract}

Keywords. asset mapping, sheep farming, traditional Islamic boarding school, pesantren

\section{Background}

Sheep is a small ruminant mostly raised by most breeders in Indonesia that became the primary choice for novice breeders because they are farm resistant to disease, easy to feed, and fast business rotation. Sheep also have other advantages over goats; for example, they are not susceptible to common diseases, namely bloat, and scabies and are not too picky in terms of feed. Indonesian people widely consume sheep meat, and the demand increases sharply on the annual Muslim celebration, namely the time of Eid al-Adha. The sheep population is increasing from 2014 to 2018: in 2014 was 17,024,685 heads: 2015 was 15,716,695 heads; 2016, namely 17,142,498 heads; 2017, namely 17,611,392 and 2018, namely 17,794,344 heads (Livestock and Animal Health Statistics, 2019). Having those advantages, then sheep became mainly 
chosen by people who do not have the expertise in livestock farming but try to start the new one.

Bettencourt et al. (2015) state that the livestock social functions correspond to the symbolic values associated with each species and the use of animals for the fulfillment of a set of rituals and social obligations of families and communities. Livestock gives social status to its owners once it is considered a common means of demonstrating wealth and provides economic status. It facilitates access to informal credits and loans to households. Livestock is also used in traditional rituals, ceremonies, and festivities and as a gift in worships (e.g., installation of ancestral spirits, ritual slaughter, bridewealth).

Rural life in Indonesia, where most of the population is Muslim, is closely related to the Traditional Islamic Boarding School. Traditional Islamic Boarding School is an institution that takes the role of religious education and non-formal education for people who have difficulty joining formal schools. Most parents choose to send their children to Traditional Islamic Boarding School because of the low cost (even free), and the learning time is very flexible. Besides, the Traditional Islamic Boarding School provides additional moral and religious education that cannot be provided by parents. Children who enter the Traditional Islamic Boarding School or commonly referred to as "santri," is expected to have religious provisions and be able to read and write as the basis for formal education if they have funds for formal schools. Santri at Traditional Islamic Boarding School is human resource assets (classified as youths) can be directed as the next generation of farmers.

Asset mapping is needed to plan the development program of a sheep business center. Asset mapping is an activity to map the resources owned by an area before an empowerment program is carried out. Asset mapping includes six mapping areas: physical, natural, human, technology, financial, and social capital. This asset mapping is crucial for planning village development programs and community empowerment. Some things that are usually considered as weaknesses, in contrast to asset mapping, are seen as regional assets from a different perspective. Key attributes of community members: People who have a passion for their neighborhood and the health of its residents. People who have a history of being "connectors"(A lot of relationships). People who are respected in their neighborhood who have gotten things done in their associations will commit the time necessary (Duncan, 2016).

This study aims to map the existing assets (physical, natural resources, human resources, financial, technology, and social capital) of Ngawonggo Village, Tajinan District, Malang Regency. The result of asset mapping is used as a strategic base to conduct a development program sheep business carried out by the Traditional Islamic Boarding School in the village. The Traditional Islamic Boarding School in Ngawonggo Village, named Pondok Angkring Fatchul Ulum, was founded in 2010 by Ustadz (the religious term for teacher) Habib, who has 50 students. Hopefully, sheep farming can make Traditional Islamic Boarding School and its students financially independent. The long-term target is that Ngawonggo Village can become a sheep business center to empower all levels of society in the region.

\section{Literature Review}

\subsection{Sheep Farming}

Indonesia is a country where agro-ecological conditions are believed to have an important impact on small ruminants kept. However, in all agro-ecological zones, both sheep and goats can be found. Farmers, policy-makers and scientists perceive that the availability of better quality forages in multiple cropping systems in higher altitude areas make these areas suitable for goats, because they believe that goats need better quality feed and thrive better on tree leaves (Budisatria et al., 2010). Prices were relatively high during periods of Muslim religious 
festivities and relatively low during periods of urgent cash needs, which was mainly the case at the end of the dry season (August-September) when cash is needed for land preparation and payment of school fees (Budisatria et al., 2010).

The number of goats and sheep is kept rising along with the increase of the human population, but the increase of the goat and sheep population cannot keep up with the demand for its meat. Because of that, there is a shortage of supply for goat and sheep meat in Indonesia. But with that condition, goat and sheep fattening is not very popular and still uses a traditional way to breed and grow it (Febrianno and Siahaan, 2012).

While the goat characteristics are: could be breed in an extreme climate condition, need a long time to adapt to a new environment, walk a long distance, and have a high reproductive rate. The location of the farm needs to be determined very carefully. Some factors need to be considered in choosing the farm location are:

1. Environmental conditions: land contour, temperature, and humidity. Land contour to breed sheep and goat should be flat to ease sheep and goat raise. Besides that, with flat land contour, it will reduce the cost to build the barn.

2. Natural resources around the farm location are also significant in build a farm for sheep and goats. An area with a lot of natural resources will ease the fattening process of sheep and goats. The resources are water supply and food supply. Water supply can be: the river, ponds, or land water. If the location is easy to get water supply, it will reduce the transportation cost to get water (Febrianno and Siahaan, 2012).

\subsection{Traditional Islamic Boarding School Role in Rural Area}

Mustali (2020), with the government, many Islamic boarding schools collaborate in village development such as agriculture, animal husbandry, cooperatives, small businesses, etc. 7. In addition to delegating assistance to the Regional Level Implementation Unit (UPTD), the central government often assists directly with the pesantren because it can be considered a pilot project of development to the surrounding community.

More importantly, the problem of undersupply of teachers might contribute to the big gap between urban and rural areas in terms of inputs, process, access, equality, equity, and efficiency and might lead to poor student performance. The findings of our study provide a clear picture of underprivileged circumstances related to quality teachers at pesantren. Another interesting finding in our study was that part-time teachers never complained if they did not get their small salary although they had been teaching for quite a long time. These kinds of characteristics make pesantren exist to provide education for students in rural and remote areas where public schools do not exist (Muazza et al., 2018).

\subsection{Asset Mapping}

Asset mapping is not just for listing the assets of a community from an area. It is a strategy to identify assets that are available from within the community. More importantly, it is a process for connecting and engaging the community and unlock the talents of people to help solve problems and build a better society. The results of asset mapping are used to make the members of the community aware of what they have and can work together to improve their lives. (Duncan, 2016).

Asset mapping is a community development technique and also a research technique. A review of the social work literature reveals that only a handful of studies use asset mapping as a research technique. The data obtained from asset mapping can be used by researchers to get strength points from a community to solve community problems. The research data generated from asset mappings, such as asset inventories or asset maps, can be used as dependent or independent variables in the research process. Asset mapping is not necessarily 
participatory, as a research team could hire its asset mappers. The participation of community members in collecting data from asset mapping can increase the validity of the data. A participatory approach also allows social work researchers to develop strong partnerships with community (Lightfoot et al., 2014).

\section{Research Methodology}

The study was conducted in Ngawonggo Village, Tajinan sub-district, Malang Regency, from July to August 2020 to find the existing assets (physical, natural resources, human resources, financial, technology, and social capital). The methods used in the research was qualitative research and used two sources of data: primary and secondary data. Primary data was collected from key informants who were chosen purposively then continued by the snowball sampling method. There were four key informants: the head of a traditional Islamic boarding school, the head of woman organization, the informal leader of sheep breeders, and the head of a village cooperative. Ngawonggo Village office documents were the source of secondary data. Data collected then analyzed by descriptive data analysis.

\section{Result and Discussion}

\subsection{Physical Capital}

The division of Ngawonggo Village is currently divided into 4 Hamlets or Rukun Warga and has 39 Neighborhood Associations. Water sources from rivers in the Ngawonggo Village area form the Manten River Basin (DAS) pattern. Several irrigation connections in Ngawonggo Village, namely:
1) Ngawonggo Village Irrigation Connection
2) Irrigation Connection Towards Kasembon Village, Bululawang District
3) Irrigation Network Towards Kidangbang Village, Wajak District
4) Irrigation Network Towards Pringu Village, Bululawang District

The education sector in Ngawonggo Village has facilities that include kindergarten to high school levels. Table 1 shows the number of students who can enter formal schools in the village.

Table 1. Educational Institution Data

\begin{tabular}{|c|l|c|c|c|}
\hline No & $\begin{array}{c}\text { Educational } \\
\text { Institutions }\end{array}$ & $\begin{array}{c}\text { Number of } \\
\text { institutions }\end{array}$ & $\begin{array}{c}\text { Number of } \\
\text { teachers }\end{array}$ & $\begin{array}{c}\text { Number of } \\
\text { students }\end{array}$ \\
\hline 1 & Child care & 1 & 2 & 32 \\
\hline 2 & Kindergarten & 3 & 10 & 146 \\
\hline 3 & Elementary school & 2 & 32 & 297 \\
\hline 4 & Junior High School & 1 & 8 & 162 \\
\hline 5 & Senior High School & 1 & 6 & 67 \\
\hline 6 & University & - & - & \\
\hline 7 & Islamic Boarding School & 2 & - & \\
\hline
\end{tabular}

In conditions of limited educational facilities, the role of Islamic boarding schools becomes essential. Islamic boarding schools are a low-cost alternative to education and provide main life guidelines. Muklasin in Sulaiman et al. (2018), Boarding School/Pesantren, can be managed by the process of determining educational programs and its evaluation by involving the community and graduate Santri to ask for input concerning the development of moral character and prosperity together. Pesantren is very appropriate for carrying out the 
empowerment because as a multifunctional institution in the field of education, religious, social, and civic education process to have an unlimited amount of time, and still believed by people, especially in rural areas (Zubaedi in Sulaiman et al., 2018).

Religious facilities are dominated by Islamic religious facilities, which are adhered to by most community members.

Table 2. Worship Places

\begin{tabular}{|l|l|c|}
\hline No & \multicolumn{1}{|c|}{ Worship Places } & Number \\
\hline 1 & Masjid/Mosque & 5 \\
\hline 2 & Mushola/Small private mosque & 27 \\
\hline 3 & Surau/Small public mosque & 4 \\
\hline 4 & Qur'anic Kindergarten & 14 \\
\hline 5 & Church Total & - \\
\hline \multicolumn{2}{|c|}{ Total } \\
\hline
\end{tabular}

(Source: Ngawonggo Village Office Document, 2019)

The infrastructure that supports transportation is shown in the following table.

Table 3. Village Infrastructure

\begin{tabular}{|c|l|c|}
\hline No & \multicolumn{1}{|c|}{ Village Infrastructure } & Number \\
\hline 1 & Regency road length & $2.3 \mathrm{~km}$ \\
\hline 2 & District road length & - \\
\hline 3 & Village road length & $12 \mathrm{~km}$ \\
\hline 4 & Irrigation length & $16.8 \mathrm{~km}$ \\
\hline
\end{tabular}

(Source: Ngawonggo Village Office Document, 2019)

Other problems that arise due to the lack of village facilities and infrastructure are:

1. There are still many houses that are unfit for habitation, namely the physical condition of the house consisting of dirt floors and woven bamboo walls.

2. Many public toilets are damaged

3. About $30 \%$ of village roads and alleys without electricity

4. There was a narrowing of the public burial ground directly adjacent to the community's land.

5. There are still many school buildings that still lack study spaces and other educational facilities, such as teacher rooms, laboratories, library rooms, and so on.

The asset mapping regarding the facilities and infrastructure above can explain why social problems occur in a community. Dorfman (1998) states that asset mapping reveals and explores those resources and assets. Data on assets owned by a community determines the relationship between assets, how community members can access these assets, and how they can use it in building their community.

4.2. Natural Capital/Resources

Ngawonggo Village already has facilities that include kindergarten to high school levels. Ngawonggo Village is an area of T Crafts District, Malang Regency, with 375,628 hectares. Plains with an average elevation of $700-800 \mathrm{~m}$ above sea level. Administratively, the Village area is located at the southern tip of Takarya District, which is directly adjacent to Wajak District with the following boundaries:

Northside: Purwosekar Village, Tajinan District

Eastside: Ngunggung Village, Wajak Subdistrict 
Southside: Kidangbang Village, Wajak Subdistrict

Westside: Pandanmulyo Village, TajinanDistrict

It is $4 \mathrm{~km}$ from Ngawonggo Village to the subdistrict capital, which can be reached in about 15 minutes. Meanwhile, the distance to the district capital is $20 \mathrm{~km}$, which can be reached in about 0.7 hours. Also, the mainsprings that can be used as a source of clean water and a source of water for agriculture in Ngawonggo Village include:

1) Sumber Gambreng spring located in Sidomakmur Selatan Hamlet

2) Urung-urung Springs located in Sidomakmur Selatan Hamlet

3) Sumber Buntung spring located in Sidomakmur Utara Hamlet

4) Cuban Spring located in Irodipo Hamlet

5) Mbah Irodipo spring located in Irodipo Hamlet

The following are sources of clean water that are active during the dry season and the rainy season are artesian well 1.106 units, municipal waterworks in 4 locations dan one river.

Most of the land use in Ngawonggo Village used productively which shows that the area of Ngawonggo Village has adequate natural resources and is ready to be processed. The land area of Ngawonggo Village is $375,628 \mathrm{Ha}$. The existing land area is divided into several purposes, grouped as for public facilities, settlements, agriculture, plantations, economic activities, and others. The land area occupancy is 3,596 Ha, for agriculture is $126,645 \mathrm{Ha}$, fields and moor is 182,313 Ha. Land area for public facilities are as follows: $0.136 \mathrm{Ha}$ for offices, $0.284 \mathrm{Ha}$ for schools, $0.600 \mathrm{Ha}$ for sports, and $0.638 \mathrm{Ha}$ for public cemeteries.

The commodities bred in Ngawonggo Village are various. There are several locations for fisheries and livestock: one location for fisheries and 7 for chicken, 12 for the duck, 50 for sheep /goats, 70 for cattle, and 6 for rabbit locations. Fisheries and livestock are very potential sectors, considering that forage is easily available in Ngawonggo Village. There are 16 locations for sugarcane, 21 for Albizia chinensis, 13 for bamboo, 33 locations for secondary crops, and 20 locations for coffee plantation. Livestock production is closely interrelated with crop production. The use of livestock and its sub-product manure are essential in crop production. Livestock is a source of energy providing draught animal power while manure improves soil structure and fertility, and water retention. Both uses are environmentally friendly, improving energy and nutrient cycling. Livestock is also used to transport agricultural inputs and outputs and people. Livestock production is an important means of exchange between rural households and when sold, contributes to boost and strengthen rural markets. Rural markets are an important piece in the operation mode of rural communities and a significant contribution to rural families' wellbeing and wealth (Bettencourt et al., 2015).

\subsection{Human Capital/Resources}

Human resources, which can be seen in several ways such as population, population development, education level, population livelihoods. The Social Condition of the Villagers of Ngawonggo. The total population of Ngawonggo Village is 4201 people, with details of 2,114 men and 2,087 women who are members of 1283 households.

The community's motivation to pursue formal education is deemed insufficient. Children are often forced to skip school when harvest time to help their parents. Meanwhile, the education level of the residents of Ngawonggo Village is as follows:

\section{Table 4. Education Level}

\begin{tabular}{|c|l|r|}
\hline No & \multicolumn{1}{|c|}{ Education Level } & Number of people \\
\hline 1 & Illiterate people $>10$ years old & 16 \\
\hline 2 & Not finish elementary school & 713 \\
\hline 3 & Finished Elementary School & 1.229 \\
\hline
\end{tabular}




\begin{tabular}{|c|l|r|}
\hline 4 & Finished Junior High School & 953 \\
\hline 5 & Finished High School & 297 \\
\hline 6 & Hold Bachelor/Diploma Degree & 16 \\
\hline Total Number & 3.224 \\
\hline
\end{tabular}

(Source: Ngawonggo Village Office Document, 2019)

Children and teenagers who drop out of school who do not continue formal schooling are become santri at Islamic boarding schools or choose to work in the informal sector. The high number of people with low education creates new problems such as unemployment and urbanization. Those looking for work in the cities usually find work as seasonal laborers. They return to the village as unemployed workers again if they do not get a job.

The problems that exist include:

1) Many poor people are unable to send their children to a higher level because of unaffordable education costs

2) The number of youth lacking skills

3) The people's perspective on education levels is still lacking.

Table 5. Human Resources Problems in Ngawonggo Village

\begin{tabular}{|r|l|r|}
\hline No & \multicolumn{1}{|c|}{ Human Resources Problems } & $\begin{array}{c}\text { Number of } \\
\text { people }\end{array}$ \\
\hline 1 & Street children & 1 \\
\hline 2 & Prostitute & 1 \\
\hline 3 & Ex prisoner & 1 \\
\hline 4 & People with disabilities & 21 \\
\hline 5 & Families under the poverty line & 388 \\
\hline 6 & People with mental disabilities & 63 \\
\hline 7 & Families with improper house & 4 \\
\hline 8 & Scavenger & \\
\hline
\end{tabular}

(Source: Ngawonggo Village Office Document, 2019)

In general, the problem occurs due to the large number of unemployed and orphans who do not get enough attention from the government. Farmers also have problems because many are still tied to the bonded bond system. Also, farmers' knowledge and skills in absorbing new technology are still lacking. This is the importance of asset mapping that serves as a useful tool for understanding the wealth of talent and resources in each community - even those with small populations or suffering from poverty and economic distress. The longterm development of a society rests on its ability to uncover and build on the strengths and assets of its people, institutions, and informal organizations. Included are creative strategies to identify and tap the wealth of leadership potential available in every community. However, to be truly effective, asset mapping must take the essential step of linking these various talents and resources together (Beaulieu, 2020).

\subsection{Financial Capital}

Most of the population work as farmers and has livestock as a side income. The livestock that is kept is beef cattle, goats, and rabbits. About $30 \%$ of people of productive age do not have permanent jobs. 
Table 6. Occupation

\begin{tabular}{|l|l|r|}
\hline No. & \multicolumn{1}{|c|}{ Occupation (sector) } & Number of people \\
\hline 1 & Agriculture & 2.971 \\
\hline 2 & Service & \\
& $-\quad$ Government & 25 \\
& $-\quad$ Trades & 57 \\
& $-\quad$ Transportation & 24 \\
& $-\quad$ others & 34 \\
\hline 3 & Industries & 95 \\
\hline 4 & Others (tourism, household business, etc.) & 396 \\
\hline
\end{tabular}

(Source: Ngawonggo Village Office Document, 2019)

Efforts to smoothen the economy by building public infrastructure (construction of roads, drainage, bridges, rehabilitation of the Village Market) additional business capital through cooperatives or SMEs, and counseling increase community income. They are improving services in the health sector utilizing: construction of Polindes, procurement of ambulances, repair of toilets, provision of clean water through Dongki water pumps installation, meters and construction, utilization, maintenance of educational facilities and infrastructure through the construction of child care buildings, Qur'anic Kindergarten, mosque rehabilitation, prayer room, and furniture procurement as well as for improving the welfare of teachers and other needs related to the livelihoods of the Ngawonggo Village community. One of the most visible financial problems is that the existing BUMDES (Village Financial Support) are not running optimally.

The existence of Islamic boarding schools in the face of a lack of financial support is to nurture their students to become economically independent, raising livestock. Based on the preceding, the study of the dynamics of the Pesantren into an exciting and vital especially role of Pesantren as religious institutions, social and economical in improving the welfare Pesantren and Islamic student (Santri), because it has experience and expertise in the economy or entrepreneurship. So Santri, after graduation from Pesantren, can play a role in the development process of both mental and spiritual, moral, social, and economic progress brings in people's lives. The religious education, social, and Economics at Pesantren is very relevant to the concept of Islam carry out a balance between the life of the world and the hereafter as well as a mercy for all of the world (Rahmatan Lil'aalamiin) (Sulaiman et al., 2018).

\subsection{Technology Capital}

Many productive businesses have traditional patterns related to production patterns, technology, business partnerships, and marketing patterns. People need entrepreneurship/ business management training and marketing management to grow well and prospectively. Some of the problems in technology have an impact on the following:

1. Inadequate abilities and skills in terms of improving the quality of production

2. Difficulty in marketing the products because many similar products are of better quality.

3. Difficulty in diversifying the business

4. Lack of information skill

Animal husbandry activities, mainly sheep farming, are expected to overcome the shortage of technological capital from the people of Ngawonggo Village. Because animal husbandry has been carried out over the years in the community, it is not done professionally. Sheep are considered appropriate because they have almost the same characteristics as the 
goats bred so far. Besides that, sheep also have several advantages over goats. Sheep is preferable than goat because some of the characters that the sheep have which are:

1. Sheep is easy to adapt to the new environment

2. Sheep live in a cluster, so they are accessible to pastured

3. Sheep is fast to breed

4. Sheep is more resistant to disease

5. Sheep meat is tenderer and not smelly like goat meat (Febrianno and Siahaan, 2012).

4.5. Social Capital

Culture is a form of social capital and is a way for community members to communicate. This culture is a hereditary activity, and some are the result of cultural assimilation. Some active cultural activities are Patrol Campursari, Qasidah/Marawis, Terbang Jidor, Ishari, Albanjari, Cultural Ceremony, Drum band, Sakerah Marlena. Wayang or traditional dancing performance is not active anymore. Active status means still often doing routine exercise, and inactive status means the group does training only before performing. It turns out that the youth are also active in positive activities, so that they are also considered the potential to become the social capital of Ngawonggo Village. The activities include soccer, badminton, volleyball, and gymnastic. Apart from those positive sides, some data show social problems from Ngawonggo Village. Many types and arts groups still exist but are not managed optimally due to a lack of facilities.

The following are the daily social capital activities of members of the Ngawonggo Village community:

1. Norms related to rules, traditions, and figures in society. Pesantren plays a significant role in maintaining the norms and rules in Ngawonggo Village so that the business of using assets requires cooperation with the pesantren. The rules and norms are based on Islamic law.

2. Trust. Trust is an activity to take risks based on the desire to work together for a business that benefits others. All key informants are willing to work together to realize the sheep business.

3. Network. Based on shared beliefs in religious beliefs, the network between community members and pesantren led by Ustadz Habib is very close. This kind of networking has both a negative and positive side. On the negative side, this network is difficult to develop because trust in outsiders is low. Still, trust between members can give a strong will allow good cooperation in doing the business.

These three social capitals are significant for the development of the sheep business in Ngawonggo Village. Lesser (2000) states that social capital is significant for the community because (1) it makes it easy to access information for community members; (2) become a power distribution medium in the community; (3) developing solidarity; (4) allows mobilization of community resources; (5) enables mutual achievement; and (6) forming collective behavior and community organization.

\section{Conclusion}

There are six (physical, natural resources, human resources, financial, technology, and social capital) of Ngawonggo Village, Tajinan District, Malang Regency. Lack of physical, technological, and financial assets has a positive side where people will have a stronger motivation to improve their wellbeing. The potential of natural assets, human resources, and social capital can solve community problems and improve other assets that are not yet optimal. 
The sheep breeding business initiated by the pesantren as an influential institution is a strategic plan to develop the Tajinan Village as a center for sheep farming.

\section{Suggestion}

The government should undertake routine asset mapping to help the development process with participation of community members.

\section{Acknowledgments}

Special thanks to the Institute for Research and Community Service, Universitas Brawijaya, for the Doctoral Grant Scheme Year 2020.

\section{References}

[1] L J. Beaulieu. 2020. Southern Rural Development Center Mapping the Assets of Your Community: A Key Component for Building Local Capacity http://srdc.msstate.edu/publications/227/227_asset_mapping.pdf

[2] E.M.V. Bettencourt, M. Tilman, V.Narciso, M. L. da Silva Carvalho and P. Damião de Sousa. 2015. The Livestock Roles in the Wellbeing of Rural Communities of TimorLeste. Henriques RESR, Piracicaba-SP, Vol. 53, Supl. 1, p. S063-S080, 2015 Impressa em Março de 2015

[3] E. Boyle. 2002. The failure of business format franchising in British forecourt retailing: a case study of Shell Retail's forecourts. International Journal of Retail \& Distribution Management, 30: 251-263.

[4] E. Lesser. 2000. Knowledge and Social Capital: Foundations and Applications. Butterworth-Heinemann Publisher. ISBN 978-0-7506-7222-1

[5] D. Dorfman. 1998. Strengthening Community Education: The Basis for Sustainable Renewal Mapping Community Assets Workbook. Northwest Regional Educational Laboratory Rural Education Program 1998.

[6] D. Duncan. 2016. Asset Based Community Development, Clear Impact 2016, https://clearimpact.com/solutions/asset-based-community-development/.

[7] E. Febrianno and U. MMP Siahaan. 2012. Investment Analysis On Goat And Sheep Fattening Project Based On The New Food Fermentation Farming Method (3f Method). The Indonesian Journal Of Business Administration. Vol. 1, No. 9, 2012: 613-621

[8] E. Lightfood and Simmelink McCleary, Jennifer and Lum, Terry Y. (2014). Asset Mapping as a Research Tool for Community-Based Participatory Research in Social Work. Social Work Research. 38. 59-64. 10.1093/swr/svu001

[9] I.G.S. Budisatria, H.M.J. Udo, C.H.A.M. Eilers, E. Baliarti, and A.J. van der Zijpp. 2010. Preferences for sheep or goats in Indonesia. Small Ruminant Research 88 (2010) 1622

[10] Indonesian Livestock and Animal Health Statistics 2019. http://ditjenpkh.pertanian.go.id.

[11] Investment Analysis On Goat And Sheep Fattening Project Based On The New Food Fermentation Farming Method (3f Method) Erlangga Febrianno And Uke Mmp Siahaan School Of Business And Management Institut Teknologi Bandung, Indonesia Erlangga.F@ Sbm-Itb.Ac.Id. The Indonesian Journal Of Business Administration Vol. 1, No. 9, 2012: 613-621.

[12] M. Mustari. 2020. The Management of Community Education in Rural Areas by Religious Educational Institutions. Temali: Jurnal Pembangunan Sosial, Volume 3 No. 
1 the Year 2020 E-ISSN: 2615-5028 pp 236-259

[13] M. Muazza, A. Mukminin, A. Habibi, M. Hidayat, and A. Abidin. 2018. Education in Indonesian Islamic Boarding Schools: Voices on Curriculum and Radicalism, Teacher, and Facilities. The Islamic Quarterly 62(4):507-536. December 2018.

[14] A. I. Sulaiman, Chusmeru, and Masrukin. 2018. Strategy of Cooperative Islamic Boarding School as Economic Empowerment Community. INFERENSI, Jurnal Penelitian Sosial Keagamaan. Vol. 12, No.1, Juni 2018. Pp 25-44. http://dx.doi.org/10.18326/infs13v12i1.25-44. 